\title{
BEST PRACTIGES OF THE SOCIAL INNOVATIONS IN THE FRAMEWORK OF THE E-GOVERNMENT EVOLUTION
}

\author{
Vasja Roblek ${ }^{*}$, Mirjana Pejić Bach' ${ }^{2}$ Maja Meško ${ }^{3}$ and Tine Bertoncel ${ }^{4}$ \\ ${ }^{1)}$ Faculty of Organisation Studies, Slovenia \\ ${ }^{2)}$ University of Zagreb, Faculty of Economics and Business, Croatia \\ ${ }^{3 / 4)}$ University of Primorska, Slovenia
}

\author{
Please cite this article as: \\ Roblek, V., Bach, M.P., Meško, M. and Bertoncel, T., \\ 2020. Best Practices of the Social Innovations in the \\ Framework of the E-Government Evolution. \\ Amfiteatru Economic, 22(53), pp. 275-302.
}

\section{Article History}

Received: 10 September 2019

Revised: 12 November 2019

Accepted: 13 december 2019

DOI 10.24818/EA/2019/53/275

\begin{abstract}
The social innovations have been together with the advanced technology in the $21^{\text {st }}$ century, taking an essential role in social structures and their informatization processes. Information technology has become an indispensable factor not only in industry and service businesses, but also in governing systems at the micro (cities and regions) and macro (state and nations) levels. The information processes, which includes automation, have in the last few years an important impact on the transformation from "classical" governance into the "smart governance". In the paper are presented the best practices which show how could social innovations, together with the advanced technology also lead to the several democratic changes in the urban environment. It can be concluded that it will in many ways reorganize public decision - makings, create changes in democratic processes that are in accordance with socioeconomic and technological development, and will represent the basis for the emergence of the so-called the smartest social community and the ensuing novel processes of organization and operation.
\end{abstract}

Keywords: best practices, e-government, e-participation, governance, public value theory, smart governance, social innovations

JEL Classification: D71, D72, D73, O33, O35

\footnotetext{
*Corresponding author, Vasja Roblek - vasja.roblek@gmx.com
} 


\section{Introduction}

Since the beginning of e-government, humanity has undergone several social and political changes, technological developments and economic crises, most of which have been an impetus for revitalizing socio-economic development, notably with new business models in public and private sectors and increasing investment in research and development (R\&D). Probably the most important policy measure, with far-reaching implications for society, was presented by the German government in 2011. This political strategic policy, known as the 4th industrial revolution or Industry 4.0, is based on high- tech strategies (Mosconi, 2015; Bertoncel et al., 2018) and different innovations, such as the Internet of Things (IoT), Internet of Services (IoS), cyber-physical systems, blockchain technologies, big data and hyperconnectivity (Hitpass and Astudillo, 2019). The reorganization of work in public administration and the introduction of information technology is a crucial period of the Third Industrial Revolution (1950-2010), in which computerization, work automation and digitization of processes in public administration took place (Ceruzzi, 2003).

Establishment of e-government, as a public service that implements innovative ITC solutions, has played a role throughout this process, with the goal of improving existing relationships and interactions between a government and its citizens (Sa, Rocha and Cota, 2016). From the mid-1990s onward, ICT's have positively transformed the provision of traditional government public administration service into governance process (Henry, 2010). Socio-technological development has led to organizational transformation, adoption of political administration and the public apparatus. ICT is considered to be the most effective means to deliver public services to citizens and businesses, particularly internet technologies and applications (Carter et al., 2016; Sivarajah, Irani and Weerakkody, 2015). The implementation of e-government provides benefits (e.g. convenience, efficiency, lower costs and increased transparency) for its stakeholders (Rowley, 2011; Nguyen, 2016). An important transformational step (from bureaucratic public model to post bureaucracy model) happened in the 21st century with the emergence of new forms of digitalisation and informatization, which have changed the organisation and working processes of the public apparatus (Paulin, 2019). This technology has enabled that not only e-services, but also contemporary democratic models (partisan democracy, direct democracy, participative democracy, liberal democracy deliberative democracy and liquid democracy) to become a reality, especially in local urban centres, the establishment of which was previously prevented due to technical reasons or associated high-costs. Digitalisation, informatization and virtualization make available new approaches to social innovation that enable (via digital platforms and cyber-physical systems) the transformation of the present representative democratic patterns into more direct ones. When introducing new social innovations with the support of technology for improving democratic governance, we need to be aware that this it is going for a complex and demanding process (development, testing, stakeholder analysis, elimination of weaknesses, testing and final implementation). We need to first receive support within the local community (by all its stakeholders), before being introduced at the regional or national level (with a bottom-up approach).

The lack of accessibility to this infrastructure and the lack of staff has likely had a significant impact on unsuccessful e-government project implementation in developing countries, where only approximately $15 \%$ of the projects succeeded (Heeks, 2008). According to the United Nations e-government survey in 2018 (United Nations, 2018), European countries are leading the development of e-government globally; the Americas 
and Asia share almost equal standing in high and middle e-government index levels, and many African countries continue to struggle to improve their e-government standard.

The R\&D in governance focuses on the possibilities of establishing digital selfgovernance/non-mediated governance in a smart urban environment (Greiman, 2018; Paulin, 2019).

According to Rehena and Janssen (2019), a smart environment aims to implement a citizencentric use of information and interactive communication technologies. The use of innovative urban products and services is creating a new business model, and it is as such important that urban management evolves, with the interplay of local citizens and stakeholders, which are directly impacted by the informatization transition.

The implementation of ICT cannot bypass political agendas, such as new public management and post-bureaucratic model. These models have significantly contributed not only to understanding the role of ICT in public administration, but have also been transforming the organizational structure (Höpfl, 2006; Kira and Forslin, 2008; Laffin, 2018; Pollit and Bouckaert, 2011; Symon, 2000; Weerakkody, Janssen and Dwivedi, 2011), bureaucratic processes (Cummings and Worley, 2008; Paulin, 2019; Scholl, 2003; Thompson and Alvesson, 2005) and significantly have influenced the contribution of greater democratization of society with innovative technological social projects (e.g. open government, platforms for participative budgets, voting platforms etc.) which are enabling more positive (less clientelist, corruption, fraud, while increasing transparency etc.) roles in political administration and public administration (Rowley, 2011; Nguyen, 2016). On the other hand, the increasing technologization of public administration brings new societal challenges (e.g. cybersecurity, techno - populism, de-politicization, de-bureaucratisation, smart governance, open governance; nonmediated governance, public data monopolization etc.) (De Blasio and Sorice, 2018; Giddens, 2009; Florida, 2010; Meier and Bolivar, 2016; Paulin, 2019; Shires and Smeets, 2017; Zuboff, 2019).

To achieve successful development, implementation and acceptance rate of e-government, the government must be capable of defining and ensuring effective implementation of public policies (government capacity) (Kaufmann, Kraay and Mastruzzi, 2011). Within government capacity, the government must demonstrate its ability to provide credible and quality public service while ensuring a high degree of independence from political pressures (Kaufmann, Kraay and Mastruzzi, 2010; Kaufmann et al., 2011). The success of e-government also depends on the availability of particular organizational knowledge, public trust (the paradox is that Austria, which is among the first in Europe with the implementation of electronic and mobile public service, is because of a lack of confidence in cybersecurity far behind in the emergence of the e-democracy tools), social, economic and technological infrastructure. Providing or not providing all this infrastructure can positively or negatively influence the successful implementation of e-government (Kim, 2007; Suri, 2017).

The contribution of the paper is mainly conceptual and has been achieved in four phases. After the introductory part of the article, the second part includes the role of postbureaucratic models for emerging ICT in the public sector. The third explores the challenges of the role of social innovation role in democratic processes. Conclusions include a summary of the research and proposals for future research. 


\section{New organizational and governance approaches}

\subsection{Organisational approaches in the public sector}

Weber's bureaucratic model was dominated by the public sector (as well as private organizations) throughout the 20th century. Criticisms of classical public administration and the traditional model of bureaucracy came to the attention of organizational theorists and sociologists, no earlier than at the end of the 20th century, when the development of internet technologies and the process of digitalization required a different organization of work processes. At the end of the 20th century, the Weber model became the successor to post-bureaucratic model (Josserand et al., 2006). Post-bureaucracy represents the direction of development for organizations, which seek horizontal forms of organization (Höpfl, 2006; Kira and Forslin, 2008; Laffin, 2018; Symon, 2000). Post-bureaucracy becomes involved in processes of internal and external organizational change. The central internal change is directed at the functional decentralization of management structures. Horizontal coordination enables the increased use of project work and other types of self-management. Officials are expected to develop the capacity to organize themselves in the context of operational tasks and project cooperation (Miles et al., 1997).

The reform of the public sector begins with new public management, which was inspired by neoliberalism and social choice theory, because the use of normative economies in social choice are focused on the role of emerging the majoritarian electoral system (or decision-making system) (Bevir, 2016).

\subsubsection{New public management - reflections about ICT role in public sector}

Margaret Thatcher introduced new Public Management (NPM), during the early 1980s economic crisis in the UK, which was followed by United States municipal administrations and later also Australia and New Zealand, with every country gradually joining in on the effort (Barzelay, 2001). The primary purpose of the NPM was to improve the overall functioning of the public sector and to provide high-quality government services (Schedler and Scharf, 2001). Governments have sought to reduce costs, provide better services, curtail public financial shortfalls and integrate new technologies (Lindquist, 2006). Egovernment should, therefore, be of great importance in achieving these objectives (Fountain, 2001; Heeks, 2002). There have also been warnings that the development of egovernment can decrease functioning in bureaucratic institutions, which can result in diminished democratic values, such as equality and impartiality in national procedures. Therefore, ICT should act as a support for the functioning of public administration, not as a factor that reorganizes and transforms public administration (Cordelia, 2007).

Various authors (e.g., Budd, 2007; Pollit, 2009; Rhodes, 1996) believe that NPM emerged in response to the shortcomings of Weber's bureaucratic model. The NPB is also considered a paradigm for organizational transformation of the public sector and is therefore also referred to as the concept of government transformation (Dunn and Miller, 2007). As such, it should be understood as a departure from classic bureaucracy, mainly because of its focus on results, customer orientation, reduction of public administration employees, reduction of public administration costs, privatization, efficiency and effectiveness, outsourcing, breakdown, decentralization and autonomy, flexibility, competition and the use of ICT. 
It should be noted that although the use of ICT is one of the characteristics of NPM, the emergence of ICT does not have proper ground in NPM (Gruening, 2001).

In the 1990s, most NPM was criticized in Europe. Criticisms (Drechsler, 2005; Peters, 2001; Pollit and Bouckaert, 2011; Sanderson, 1998) were based on the identification of NPMs weaknesses. In response to the weaknesses of the NPM, they proposed a new perspective on public sector renewal, known as the Neo - Weberian state, which developed primarily in continental Europe. The neo-Weberian paradigm preserves Weber's elements such as representative democracy (consultable), central government, reformation and enforcement of administrative legislation and the professionalism of managers, while introducing new elements similar to the NPM principles. The purpose of these elements is to increase user orientation, increase customer engagement, result orientation and maintenance of the special status of public services (Dunn and Miller, 2007; Greve, 2010).

\subsubsection{Rise of democratic governance - New public service}

As a successor to the NPM, the New Public Service (NPS) paradigm was introduced in 2000 , defining a set of norms and practices within the foundations of public administration theory, the common feature of which is the emphasis on democracy and citizenship. The NPS focuses on developing democratic processes that involve both consultation and citizen participation in decision-making processes related to public affairs (Denhartdt and Denhardt, 2000).

Research has shown that neither the NPS nor the NPM principles have become the dominant paradigm, however, NPS has proposals and practices that follow from its models and are increasingly being recognized both in theoretical works on public administration and in public administration practice itself (Denhartdt and Denhardt, 2015a). In the context of the NPS, it is important to focus, in contrast to NMP, on the nature of public services, the role of public administration in the context of new forms of community governance (new democratically governance), and tensions over the real importance of bureaucracy, efficiency, equity, responsiveness and responsibility, the socio-cyber system and self-regulating networks (Denhartdt and Denhardt, 2015b; Rhodes, 1996, pp. 652-655).

One of the fundamental features of public administration that distinguishes it distinctly from the private sector is its relation to the public. In the private sector, companies are perceived by the public as potential or already existing customers. In the public sector, stakeholders include citizens, citizen groups, corporations, non-governmental organizations, interest groups, political parties, public agencies and other public forms of organization (Holzer and Charbonneau, 2008, p. 9). The increasingly important role of a public servant is given the task of serving citizens and the community, by helping citizens to articulate and fulfil their common goals. Thus, the work of a public servant is not focused on controlling or trying to steer society into new directions.

As mentioned earlier, the NPS focuses on the importance of government, which can be defined as the traditions, institutions and processes of determining the exercise of power in society, including how decisions are made regarding issues of public interest and what power an individual electoral vote holds in the context of acceptance or public policy decision making. Governance is about how society makes decisions and assigns and creates shared values. In this case, it is a case of a government that is socially oriented and whose 
view is rooted in coordination and co-management, as evidenced by various forms of networking and partnership. In the case of "old government", it is a more state-oriented form of government, which is oriented towards building relationships with the state (politics) of relevant actors (Peters, 2000, p. 37).

In the case of the so-called "new governance", we are talking about a political strategy that allows countries to redefine their roles in society and, consequently, increase the interest of social researchers, especially in exploring the processes of restructuring and transformation, in the light of internal and external changes. Governance thus represents an alternative to the collective social interest and supplements it through traditional institutional channels (Pierre, 2000, pp.1-3).

The impact of government on the state - public administration - is that governance has become less focused on traditional administrative processes, such as regulation and decision-making, and has focused more on inclusiveness to govern more attractive administrative processes, such as public consultation and dialogue with citizens and other stakeholders (Bingham, 2006; Raadschelders and Lee, 2011). In addition to public consultations, governance processes have focused on involving citizens and stakeholders in decision-making processes. Methods for involving citizens in decision-making processes include: consultative democracy, e-democracy, public consultation, participatory budgeting, citizen juries, study circles, standard policy formulation, alternative dispute resolution (Bingham, 2006) and citizen forums that allow the public to identify priorities for the development of launch sites and delivery of services (Moulder and Carlee, 2010).

In political administration and public administration, such responsibility extends beyond direct decision-makers to the people. Bourgon (2007) sought to close the dichotomy of public administration between political and administrative spheres and to bring them together in a shared learning environment. In this learning environment citizens would be more aware of policy-making and decision-making involved in adjusting social capacity, which would allow for a dynamic balance in society. Scientists support these shifts in the field of public administration, together with enabling citizen participation in decisionmaking on public affairs, especially at the level of local self-government (Berner, 2011; Nabatchi, 2012).

The importance of NPS is that it is based on the design of new conceptual frameworks and themes. It has thus helped to establish cross-border cooperation (Zeemering, 2008) and to the recognition, by public administration, of governance opportunities within networks that represent an opportunity for citizen participation not only in consultation processes, but also in decision-making on public matters (Nabatchi and Mergel, 2010). Thus, for example, in the Netherlands, it has influenced the development of online services and increased usage for citizens of Meijer (2011). An essential social innovation called open government was emerging at the time of the Obama administration (Open government initiative, 2009), which enables citizens to have access to government information online, an example of social innovation, which has had the effect of increasing confidence citizens have on matters in politics. For example, in the case of tax administration in the Republic of Korea, where the website reveals the budgetary position, revenues, expenditures and settlements of both central and provincial governments. Citizens can check the budget execution status online in real-time. Portals providing open access to public information in New York, the United States, and in Helsinki, Finland should also be mentioned as a tool to increase confidence and transparency (United Nations, 2018). 
The implementation of NPS is not without its obstacles and potential difficulties. Thus, all expressions of public interest resulting from the political process and dialogue are not "equally morally convincing" (Moore, 2014, p. 474). Besides, public dialogue can be directed by groups that have sufficient interest and resources to lead these processes (e.g. lobby groups). In the context of directing public dialogue, it is also worth mentioning partisan activists who are adept at conducting debates (Jacobs, 2014). However, it should also be borne in mind that the market is an effective way of directing government activities and expenditures towards the satisfaction of individual preferences. However, the arbiter of public value must be a collective public, considered incompletely formed within the processes of democratic governance (Moore, 2014, p. 475). In facilitating the realization of democratic values, facilitating public debate on public policies and the possibility of citizen participation can play an important role (Jacobs, 2014, p. 492).

After the presentation of the introduction of the organizational and new governance approaches, we further turn to the technological and the evolution of e-government, prompted by precisely this political and public scientific and sociological debate about the necessity of introducing post-bureaucratic model.

\section{Evolution of e-government}

\subsection{E-government paradigm}

The post-bureaucratic model of the public sector has, together with ICT implementation in governments and public entities, forced them to begin thinking about how to streamline the public apparatus and enhance its efficiency. In the early seventies and eighties, the IT literature in government organisations was devoted to computerization and automation (Dutton and Kraemer, 1979). With the internet and mass usage of ICT at the end of last century government and public administration launched the e-government (also called the electronic government, digital government - especially in U.S., electronic governance and similar) to increase public service efficiency, citizen participation and democratic activities (West, 2004). E-government and e-governance were first developed in the Anglo-Saxon countries (United States of America, United Kingdom, Canada, and Australia) at the end of 20 century.

E-government has two important roles:

- The first, most used and technologically advanced role is the transaction role. This role deals with how governments use e-government to improve the efficiency of public services and engage with citizens. Examples include submitting different applications and renewing a driving license (West, 2004);

- The second role of e-government, which translates into e-democracy in this section, is to enable the use of ICT to gain public support for policies and to increase citizen participation in public decision-making processes or the process of formulating of public policies (Brewer, Neubauer and Geiselhart, 2006; Stanley and Weare, 2004). E-government is thus understood as a channel of citizen participation (Ahn and Bretschneider, 2011).

This second function has been in place for the last fifteen years, with the rapid development of ICT and the establishment of cyberspace, within smart cities. It has also played a role in social change, especially in local communities. The use of ICT thus enables citizens to 
discuss important issues for the local community online, before important decisions are made. Thus, ICT enables public policy-making to pass to citizens, and it is expected that further technological development, together with social change, will reduce the impact of both politics and red tape in local communities (the process is more efficient from the bottom up).

When implementing e-government, the culture of a nation should be kept in mind. Recent research found that national culture plays a vital role in the implementation, diffusion and adoption of e-government services (Choudrie et al., 2017; Merhi, 2018; Lu and Nguyen, 2016). The five cultural dimensions, power distance, uncertainty avoidance, individualism, masculinity and long-term orientation by Hofstede have been explored in the context of egovernment. For instance, studies have shown that the adoption of e-government services are higher in countries that scored low in power distance, uncertainty avoidance, individualism, and masculinity (Merhi, 2018), while cultural dimensions were found to significantly moderate the anti-corruption impact of e-government (Nam, 2018). In addition to cross-country disparities in political and economic conditions, cultural factors were demonstrated to influence the differences in the effect of e-government on the controlling of corruption (Nam, 2019). Another study revealed that high power distance was positively correlated with user satisfaction, in regards to e- tax reports (Zaidi et al., 2017).

\subsection{E-government maturity model}

\subsubsection{The importance of social-political development for e-government changes}

The technological innovations, socio-political developments, including citizen demand and participation, have changed government roles and their environment. Governments have to react to these changes with the evaluation and implementation of new e-government policy solutions, which would, with its interaction with environmental elements result in the continuous evolution of e-government (Sangki, 2018).

The e-government maturity model based on social and political development is based on citizen participation. The model shows the degrees of social pluralism and maturity of civil society, which has increased with the development of IT and has led to the transition from an industrial society, to an information society and finally a "smart society". The model evaluates government and societal transformation by assessing its bureaucratic type, information management type, participatory type and final governance type. The final governance type presents the most integrated stages of smart government (digital government) in both horizontal and vertical terms, encompassing the integration of the entire value chain from internal businesses to external customer affairs toward procurement suppliers, private-sector partners and the general public (community stakeholders) (Sangki, 2018). Figure no. 1 presents the stages of e-government change, which form the maturity model, according to the socio-political development and level of IT R\&D. 


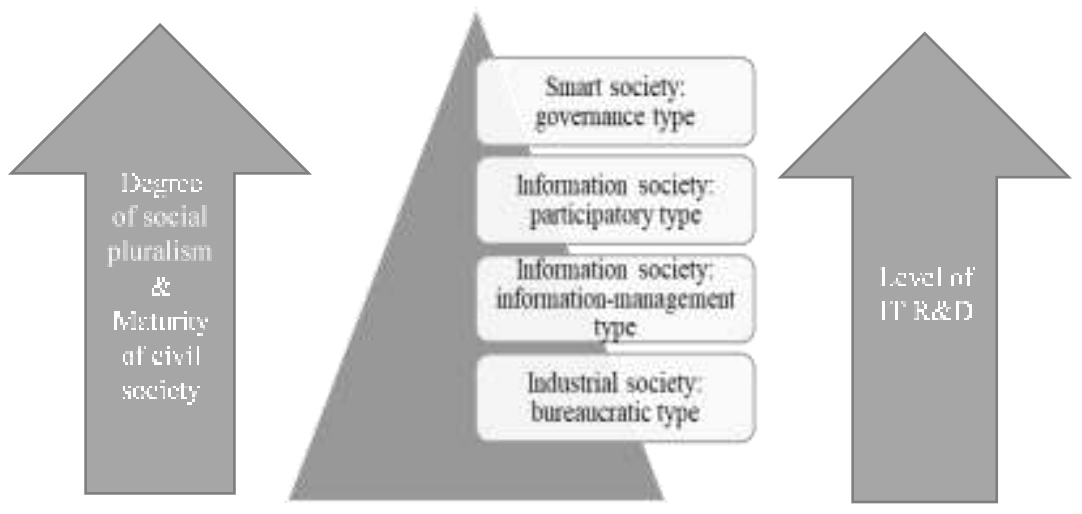

Figure no. 1: The e-Gov maturity model that is based on social-political development

Its goal is to use technology-mediated service to empower citizens and improve citizengovernment interaction while supporting public services, democracy, the private sector and other relevant entities (Layne and Lee, 2001; Bolivar and Meijer, 2016; Sangki, 2018). The implication of these facts is that e-governance is transforming governance and establishing an ideal government that is citizen-centred and is based on inclusion and integration.

The meaning of e-government and the distinction of e-governance is still unclear, despite its many years of use. Marche and Mc Niven (2003) defined e-governance as a: "Technology - mediated relationship between citizens and their governments from the perspective of potential electronic deliberation over civic communication, over policy evolution and in democratic expressions of the citizen will".

Theoretical, e-governance has also been defined as the use of ICT to support public services, democracy, the private sector and other relevant entities (Layne and Lee, 2001). E-governance is also presented as a technology-mediated service that can empower citizen - government interactions, especially in the case of smart city governance or so-called "smart governance" (Meijer and Bolivar, 2016; Sangki, 2018). It is going for the processes and technologies (civic technology) that enable citizens to access e-government channels and enhance e-democracy. The paper, thesis based on the understanding that e-governance is transforming the fourth industrial revolution, in regards to smart governance and represents the establishment of an ideal government that is inclusive, integrated and citizencentred. The e-government is understood as: "a service, that introduces consumer-level apps addressing citizen and business interaction with the state" (Paulin, 2019, p. 192). In this context, the government's goal has to be the creation of useful administrative knowledge whereby it can satisfy their consumers (users) and help the public apparatus with setting priorities and avoiding problems.

\subsubsection{The impact of the web technologies on e-government changes}

It is necessary to realize that the expectations of citizens today are quite different than they were when e-government launched in the middle of the nineties. Figure no. 2 presents 
e-government development stages, which form the maturity model according to the innovation of web technologies.

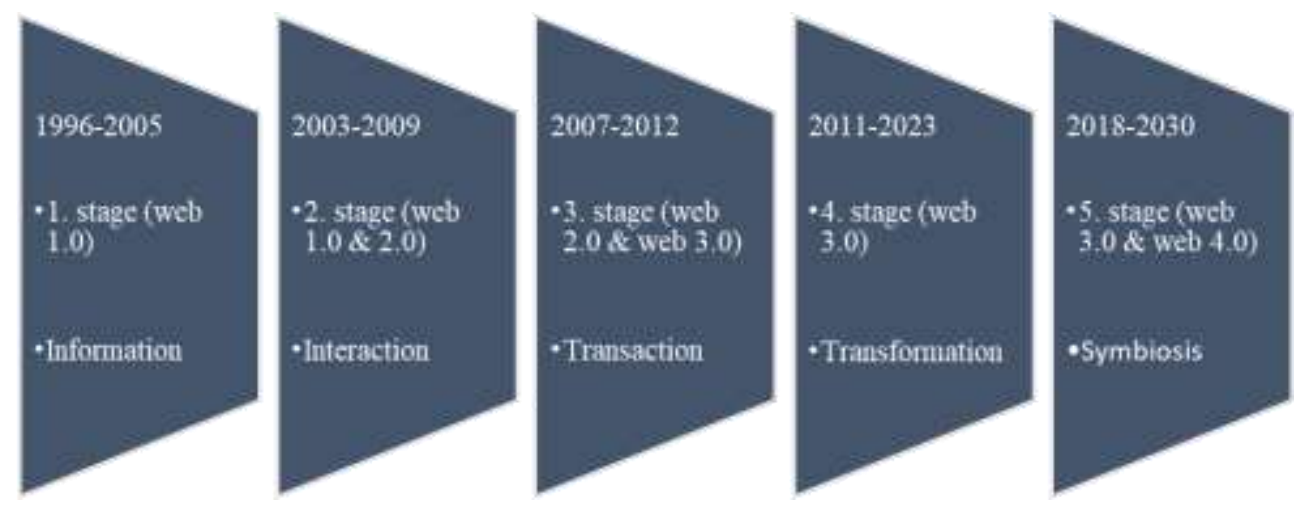

Figure no. 2: E-government maturity model: development stages according the web technology development

The first stage of development was offered to customers only in the form of contact details, which gave descriptions of the public agency and official information (address, phone, e-mail). The second stage included basic web interactive communication between public officials and customers, such as web forums to post messages or web pages, where administrative forms could be filled out or downloaded online (Paulin, 2019). By the first decade of the 21 st century, e-government became an implementation of process-oriented digital procedures (Reidolf and Prause, 2012), which in its third stage, the transactional stage, enabled administrative processes to be done online (online renews of personal documents, certificates and change of residence, firm registration, getting online information from land register and online tax return). According to the Reidolf and Prause (2012), the design of e-governmental solutions in the transactional stage should include organisational structures of public administration that focus on the reorganizing of back offices, using sophisticated backend system technologies. It should also complement, contribute and map the fourth stage, which incorporates technical substructures (standardization of data structures, engineering of protocols for data exchange, and cryptographic challenges for digital signature) (Paulin and Weltzer, 2013). The fourth stage is based on process reengineering, interconnected databases held by different bureaus, digital identity (Coursey and Norris, 2008).

The customer-oriented web services were among the 2003 and 2009 evolved the e-government to the second - interaction stage. The first stage has experienced several upgrades with newer evaluation models that have seen a variety of the positive effects, such as customer satisfaction, service quality, and user adoption (Lee et al., 2005). During these stages, performance models were developed that improved ease of website usage. The research results from different authors showed that e-government projects are successful and increase adoption and satisfaction if the user interfaces used by the government are user-friendly. It is also important, for the promotion of user access to e-government, that stakeholders adopt the behavioural changes as a consequence of the implementation of the e-government. The most important factors that influence whether or not e-government services will be implemented or not are security issues, socio-cultural practices, trust and 
privacy. Ignoring any of these factors and not closely monitoring and evaluating the implementation of e-Services (government to government - G2G; government to business - G2B; government to citizen - G2C) can lead to decreased transparency and the failure of many e-government projects (Verdegem and Verleye, 2009).

The third transaction stage $(2007$ - 2012) introduced web $2.0+$ services, which includes social media, and has, in turn, enabled social networking as a tool for citizen participation, as a form of e-democracy or participative governance (Bertot, Jaeger and Hansen, 2012; Bindu, Prem Sankar and Kumar, in press).

The current fourth transformation stage of e-government, together with a fifth stage, includes the development and implementation of digital models of e-democracy, participatory governance, and open data (Webster and Leleux, 2018). The goals of the new models are to ensure the development of cyberspace and urban data platforms as alternative e-services channels. Platforms are expected to provide greater transparency, openness, accountability and citizen participation in a government's decision - making processes (Anthopoulos, 2017a).

Development of such a communication and at the same time participatory tool has always been normative, using a social engineering approach, within which both human communication and human decision making will be carried out for a specific purpose in various aspects of society (social, economic, political, developmental programme). It is important to note that by designing software for this purpose, we reproduce and formulate new norms.

The development of such a system is essential for citizens, because it provides real-time updates, in regards to a government's actions and plans, which in turn increases the confidence of citizens in governmental work and provides them with new possibilities for participation in policy-making and the decision-making processes (Evans-Cowley and Hollander, 2010; Wilson and Chakraborty, 2019).

In the discourse on urban development strategies, several topics are discussed, such as innovative technological solutions that decrease levels of bureaucracy, increase citizen trust in government activities and increase their possibilities for cooperating in governmental decision making and public policies. The evolutionary path of e-government can be to some degree equated with a smart governance, however smart governance can be seen as a more advanced version of e-government, where increasingly advanced technologies enables the development of new forms of social innovation that can improve citizen services and participation in government processes (Bolivar and Meijer, 2016; Sangki, 2018).

From the political point of view, such innovative practice must get the trust of citizens and stakeholders (e.g. the possibilities of governmental electoral fraud in e-voting system; cybersecurity) which are presented by the political capacity to govern. The trust also has a capability (efficacy) to deliver a policy that sites perceived purpose (Citrin, 1974). If the developed and implemented policies are suited to the perceived purpose, it can be said that. The efficiency presents an essential measure for providing the value and stability of a political system. However, when is in a government apparatus introduced an innovative model, its development and implementation is not only an attribute of a political administration but also of its bureaucracy? Political administration has to have control under their bureaucracy. If it wishes to analyse the work of public administration, it has to provide according to of political control of a bureaucracy that it is making a distinction 
between the political and public administration actors and acts. These distinctions enable to provide the parsing of variables based on politics (usually independent variables) and administration (usually dependent variables) (Frederickson et al., 2012).

Table no. 1 presents the concept of e-government, as it appears in the 21 st century. It has been divided in regards to the public e-service and e-democracy model. In theory and practice, they are not known as a universal set of e-democracy models, because their development is based on different criteria. The key models that are presented have evolved over the past 25 years. The concept of e-democracy also has quite different definitions, because some authors use it in conjunction with e-government (e-democracy is understood as part of e-government), while other are using it with the term cybernetic policy and e-participation (Kneuer, 2016).

Below, we focus on the importance of e-democracy within e-government. The concept of direct, or fundamental democracy, has emerged in the period of e-democracy. It is defined as a radical contrast to the traditional form of representative democracy. Unlike participatory democracy, which limits the scope of public participation and leads to decisions that are not legally binding for the government or parliament, direct democracy is understood as a form of democracy, where citizens take control over both the planning and decision-making process and all such decisions are legally binding. A prerequisite for the establishment of such a model is the internet, which becomes a critical factor in the rise of democracy and thus replaces traditional forms of communication (Asatryan et al., 2017). Direct democracy is connected with the concept of liquid democracy. In the context of liquid democracy, a citizen decides whether he wants to participate in the decision-making process on a particular issue or to transfer his voice to someone who may be more informed about this issue or has the necessary knowledge to make a decision (Paulin, 2019). For party decision-making, it was first accepted by the German pirate party, later Demodex in Sweden began testing the implementation of LD, eventually followed by the Net Party in Argentina and the Partido de Internet in Spain. Testing integration of the model in the local governance platform for citizens decision making about public policies (platforms include e-service, e-participation and e-voting), began in London's Southwark, and in Turin and San Dona di Piave, Italy (WeGovNow, 2018).

Liberal e-Democracy allows citizens to get involved in deciding on a government programs, but their role is only indirect. It is a representative democracy in which citizens empower their representatives to represent them. Liberal e-democracy allows citizens to communicate their views and proposals to their representatives via ICT and also to communicate directly with them (Fuchs, 2006; Lindner, Hennen and Aichholzer, 2016).

Deliberative or conscientious democracy provides citizens with clear links to the decisionmaking processes, but citizens do not need to control the agenda. In this model, politicians and citizens unite with the purpose of discussion and discourse, leading to the formation of public opinion. In the background, all decisions are in the hands of voter representatives in parliament, because it is still a representative form of democracy, but requires cooperation between politicians and citizens. However, with the involvement and participation of citizens, it gives them explicit power in decision-making. Such an example of part-democracy is a consultative referendum, wherein the purpose of the implementation of consultative e-democracy is to increase the cooperation between politicians and citizens during specific electoral periods (Lindner, Hennen and Aichholzer, 2016). 
Table no. 1: E-government concept

\begin{tabular}{|c|c|c|c|c|c|}
\hline \multicolumn{6}{|c|}{ E-government } \\
\hline $\begin{array}{l}\text { Public } \\
\text { service }\end{array}$ & \multicolumn{5}{|c|}{ E-democracy } \\
\hline \multirow{3}{*}{$\begin{array}{l}\text { Deliver } \\
\text { public } \\
\text { services to } \\
\text { citizens and } \\
\text { businesses }\end{array}$} & $\begin{array}{l}\text { Citizens set } \\
\text { the agenda }\end{array}$ & \multicolumn{2}{|c|}{ Partisan democracy } & $\begin{array}{l}\text { Direct } \\
\text { democracy }\end{array}$ & $\begin{array}{l}\text { Liquid } \\
\text { democracy }\end{array}$ \\
\hline & $\begin{array}{l}\text { Government } \\
\text { (politicians } \\
\text { and officers) } \\
\text { sets the } \\
\text { agenda }\end{array}$ & $\begin{array}{l}\text { Liberal } \\
\text { democracy }\end{array}$ & $\begin{array}{l}\text { Participative } \\
\text { democracy }\end{array}$ & \multicolumn{2}{|c|}{ Deliberative democracy } \\
\hline & & \multicolumn{2}{|c|}{$\begin{array}{l}\text { Citizens are mainly } \\
\text { impicitly included in } \\
\text { decision-making processes }\end{array}$} & \multicolumn{2}{|c|}{$\begin{array}{l}\text { Citizens have an } \\
\text { explicitly defined role } \\
\text { in decision-making } \\
\text { processes }\end{array}$} \\
\hline
\end{tabular}

Partisan e-Democracy includes citizens who take part in political debates, but do not go through conventional channels and their representatives. The determination of the agenda is carried out through visible public expression, which is not limited by the government. However, in the partisan democracy, there is no decision-making and consensus on a particular topic is very rare (Carlson, 2016).

Table no. 1 presented cases when e-government systems were used. These systems combine technology, for example, tools that use ICT that help urban environment stakeholders use e-services that find government information (open data) that they need for their work, research, or for private interest. This system also enables participation in governmental processes, which includes deliberation, participation and decision-making about public policies and elections (Wilson and Chakraborty, 2019).

When state-of-the-art technologies in government cyberspace are used, it should be crucial to prevent unnecessary disclosure of both personal and corporate data, manipulation and abuse of public data and excessive control of citizens. For example, some critics have pointed out that the Chinese national information system, i.e. grid-style social management, can turn out to be problematic when considering human rights and their violation. The primary role was to facilitate communication between citizens, with public security bureaus being transformed into a distribution social service. Thus, it now allows government authorities to gain more situational awareness at the group level as a result of tracking and monitoring of individuals (Hoffman, 2017; Mistreanu, 2018).

In regards to data warehousing in a cyber environment, the issue of monopolizing the disposition and trading with public data must be emphasized. Public data has substantial value for business and society. Data and data management become core components for success and competitive advantage in many industrial and public sectors, value chains or organisational processes and thus a decisive factor for public policies and business decisions. Appropriate legislation should prescribe what public information is freely available and with which public authorities it can be traded with, in data stock exchanges, along with figuring out what will prevent monopolization and possible misuse of resale and use of data in advance (Paulin, 2019; Zuboff, 2019). 
The next chapter is focused on the importance of social innovations for democratic development.

\section{Social innovations role in democratical processes}

In the 21 st century, there has been a collective effort to expand the definition of social innovation and increase its importance. For this purpose, in 2011 the Vienna Declaration was adopted at the Social Innovation Conference (SIC). This declaration promotes social innovation as an indispensable alternative to technology-oriented innovations that cannot solve the problems of transitioning from an industrial society to a service- and knowledgebased society. According to the declaration, "such fundamental societal changes require the inclusion of social innovations in a paradigm shift of the innovation system" (Vienna Declaration, 2011).

The European Union has also recognized the importance of social innovation and corporate networks. The Committee on Economy and Social Affairs thus adopted the following position: "Social innovation and collaborative networks must be fully used in order to boost participation by the public and civil society in general in designing and managing EU policies, by means of distributed collective and bottom-up projects that strengthen more direct democracy" (EESC, 2016, C13/104).

The meaning of social innovation in the context of democratic processes has been revolutionary throughout history, which can be seen in the struggle for the right of individuals to contribute to collective decision-making regarding social change (e.g., shaping the social economy, welfare state, diverse emancipation). The issues that are important for defining and explaining the importance of different dimensions of social innovation and government in today's political environment focus primarily on the complexity of the issues of good and bad qualities of introducing direct democracy versus representative democracy. Based on a historical overview of the development of democracy, we can conclude that the theory of public choice is only one of the perspectives that enable the transformation of democracy and that we must take into account other theories, such as theories of social change, institutionalism, the theory of regimes. That gives us a better understanding of the importance of human and social forces mobilized for the development of future democracy (Moulaert et al., 2017).

The word governance is also used to refer to different circumstances and meanings. Thus, Rhodes (1996, p. 522) defines governance as self-organizing inter-organizational networks, complementing markets and hierarchies, which are leading structures for the credible allocation of resources and the implementation of control and coordination. While Kooiman (1993, p. 258) understands governance as a pattern or structure that emerges in the sociopolitical system as a typical or non-typical result of the mutual efforts of all actors involved, this pattern cannot be confined to a single actor or group of actors.

Governance has received a great deal of criticism, mainly focused on the importance of government, for example, the government without government (Rhodes, 1996, p. 677), which reflects the importance of social participation in the planning and management of public policies and services. Adopting one of these two approaches enables the transfer of power and voice to civil society to which this role did not previously belong. In the 
informatization, era governance gets the adjective "smart", which leads to new societal challenges.

If the political system wishes to coordinate and executes a process with active public participation, it has to distribute its power. This can be provided with the government's social innovations through emerging technologies that enable digitalization and informatization of processes which are already affecting urban environments and challenges their models of governance. We are emphasizing the new concepts of new innovative urban governance, which has a deliberative relation with the city stakeholders, and it enables the citizens' decision - making.

Social innovative urban governance has to provide way to avoid instability in sharing policy decision-making process with citizens (and other stakeholders), when implementing cyberspace environments, promoting citizen participation (citizens as policy "prosumers) on policy determination (including public-private collaboration for improving public performance) and interactive policy communication processes ( $\mathrm{G} 2 \mathrm{C}$ and $\mathrm{C} 2 \mathrm{G})$, which represents resident-centred policy debate and determination (Seoul Metropolitan Government, 2019). The implementation of smart governance will likely lead to a change in traditional representation in political and public administration. According to the Jørgensen (2012), it is going for an intimate, interactive partnership. (Table no. 2)

Table no. 2: Best practices of the smart urban platforms which enable stakeholder's e-Service and participation

\begin{tabular}{|c|c|c|c|}
\hline State/region/city & $\begin{array}{l}\text { Type of e- } \\
\text { government }\end{array}$ & $\begin{array}{l}\text { Name of } \\
\text { service/ } \\
\text { platform }\end{array}$ & Purpose \\
\hline $\begin{array}{l}\text { Australia/New South } \\
\text { Wales }\end{array}$ & Voting system & $\begin{array}{l}\text { iVote } \\
\text { (web platform) }\end{array}$ & $\begin{array}{l}\text { Enable to the citizens to vote online } \\
\text { or by phone for the state election } \\
2019\end{array}$ \\
\hline Austria/Vienna & $\begin{array}{l}\text { e-service, } \\
\text { petitioning, election } \\
\text { card application } \\
\text { (in option for now) }\end{array}$ & $\begin{array}{l}\text { Der digitale } \\
\text { Ausweis (mobile } \\
\text { application and } \\
\text { web platform) }\end{array}$ & $\begin{array}{l}\text { Allows citizens' business registration, } \\
\text { car registration, and city petitioning }\end{array}$ \\
\hline $\begin{array}{l}\text { Estonia/local } \\
\text { government } \\
\text { (cities and parishes) }\end{array}$ & $\begin{array}{l}\text { e-participation, } \\
\text { e-voting, } \\
\text { e-participative } \\
\text { budgeting } \\
\text { (only in Tartu) }\end{array}$ & $\begin{array}{l}\text { Volis } \\
\text { (web platform } \\
\text { and mobile } \\
\text { application) }\end{array}$ & $\begin{array}{l}\text { Paperless document management and } \\
\text { processing; different possibilities for } \\
\text { participation in meetings including } \\
\text { virtual participation;E-voting ID card; } \\
\text { Automatic self-writing session } \\
\text { protocol; Session webcast and } \\
\text { recordings archive; possibility to do } \\
\text { paperless all participatory budgeting } \\
\text { processes and use polls where } \\
\text { secure;Possibility to do paperless all } \\
\text { participatory budgeting processes and } \\
\text { use polls where secure voting by e } \\
\text { population is provided }\end{array}$ \\
\hline $\begin{array}{l}\text { Estonia/local } \\
\text { government } \\
\text { (cities and parishes) }\end{array}$ & Open data platform & KOVTP & $\begin{array}{l}\text { Open source service portal for local } \\
\text { governments is a website content } \\
\text { management solution, turning a } \\
\text { conventional website into a service } \\
\text { portal }\end{array}$ \\
\hline
\end{tabular}




\begin{tabular}{|c|c|c|c|}
\hline State/region/city & $\begin{array}{l}\text { Type of e- } \\
\text { government }\end{array}$ & $\begin{array}{l}\text { Name of } \\
\text { service/ } \\
\text { platform } \\
\end{array}$ & Purpose \\
\hline Finland/state level & Open code platform & $\begin{array}{l}\text { The citizens' } \\
\text { initiative }\end{array}$ & $\begin{array}{l}\text { It gives citizens the opportunity to } \\
\text { consider their proposal by the Finnish } \\
\text { parliament. A citizens' initiative may } \\
\text { include a bill or a proposal that they } \\
\text { should start the process of drafting } \\
\text { the bill. The initiative may also } \\
\text { concern the amendment or repeal of a } \\
\text { valid act }\end{array}$ \\
\hline Finland/state level & $\begin{array}{l}\text { e-deleberative } \\
\text { democracy }\end{array}$ & $\begin{array}{l}\text { Otakantaa; } \\
\text { Lausuntopalvelu }\end{array}$ & $\begin{array}{l}\text { Otakantaa can be used to create } \\
\text { questionnaires and discussions during } \\
\text { the drafting process; Lausuntopalvelu } \\
\text { is intended to collect official requests } \\
\text { for online statements, which is always } \\
\text { necessary before the government } \\
\text { sends the bill to the parliament }\end{array}$ \\
\hline $\begin{array}{l}\text { Italy/Emilia } \\
\text { Romagna }\end{array}$ & e-participation & $\begin{array}{l}\text { "io Partecipo +" } \\
\text { (web platform) }\end{array}$ & $\begin{array}{l}\text { in the framework of the preparation } \\
\text { of certain regional political decisions, } \\
\text { citizens have the opportunity to } \\
\text { engage in the process of participating } \\
\text { in design by joining discussions in } \\
\text { "virtual rooms". Each "virtual square" } \\
\text { is intended for the cooperation } \\
\text { process and is configured as a public } \\
\text { space in which people can exchange } \\
\text { information, discuss ideas and } \\
\text { propose solutions }\end{array}$ \\
\hline Russia/Moscow & $\begin{array}{l}\text { e-participation, } \\
\text { e-voting }\end{array}$ & $\begin{array}{l}\text { Active Citizen } \\
\text { platform app and } \\
\text { web }\end{array}$ & $\begin{array}{l}\text { It allows residents of the Russian } \\
\text { capital to allow citizens to directly } \\
\text { weigh in on non-political city } \\
\text { decisions - things like setting speed } \\
\text { limits, plotting bus routes, and } \\
\text { naming subway stations. } \\
\text { A project to implement blockchain in } \\
\text { its electronic voting system based on } \\
\text { Ethereum smart contracts platform. } \\
\text { First use september } 2019 \text { elections to } \\
\text { the Moscow City Duma }\end{array}$ \\
\hline South Korea/Seul & e-participation & $\begin{array}{l}\mathrm{m} \text {-Voting and } \\
\mathrm{e}-\text {-Voting }\end{array}$ & $\begin{array}{l}\text { This participatory policy allows } \\
\text { citizens to vote not only on policy } \\
\text { issues, but also on any ordinary city } \\
\text { life issues }\end{array}$ \\
\hline
\end{tabular}

\subsection{Importance of social learning for successful smart governance}

Smart governance approaches are theoretical and practical concepts with the potential to transform society. If we want to realize this scenario, it is necessary to provide a social learning policy and to achieve the appropriate educational structure about the liberation process of the citizens at all levels (Pitasi et al., 2018). Politicians, citizens and 
stakeholders have to understand the meaning of smart governance, as a social innovation for urban environment prosperity. In this context, the more ambitious and competent citizens become early adaptors and/or promoters of these new governance technologies.

The consequences of insufficient social learning can be seen in techno popularism which is understood as an innovation, although the relationship between populism and technology is not new in the European political scene. The critical elements of techno populism include internal egalitarianism, people organized into a social community, direct democracy, techno-libertarianism and hypermedia (technical knowledge, possession, anti-elite technocracy). It builds on factors such as corrupting, ineffectiveness and meritocracy as the rule of law, in politics and other branches of government and politics (De Blasio and Sorice, 2018).

Bickerton and Accetti (2015) wonder if there is a possibility that the struggle between the opposition between left and right can replace the "disconnection" between populism and technocracy. Müller (2017) points out that from the standpoint of technocracy, there is only one correct political solution and that populism believes that there is only one credible will of people. This statement means that both in some ways, reject a democratic debate and can be interpreted as a result of the process of de-politization?. Indeed, this is another aspect of the post-political period, the results of which are evident in the effect of de-politization and the emergence of a new form of re-politicization through technology.

One example, where social learning is lacking is Brexit in Great Britain, where the extreme right-wing politicians are providing unskilled citizens, with low levels of knowledge, with their views about the consequences of Brexit. They are working towards mobilizing a marginalized group of citizens that do not want or are not capable of accepting socioeconomic and technological changes occurring throughout society. The politician in such cases uses populism, which includes exploitations of fear and emotions of the public, disregarding the consequences (Roth, 2018). The consequences of the public mobilization are that it takes a majority with no effects. As we have seen in the campaign for the European elections of 2019, politicians use social media like Facebook and Twitter as a tool for social mobilisation, but no so much for social learning (Jackson, 2018).

Another case of populist ideology is found in Italy, where one of the leading ideologies of the Five Star Movement, Davide Casaleggio, proposed in 2018 to abolish the Italian parliament and replace it with direct Internet democracy. The answer to the opposition was, of course, clear that the populist movement wants to introduce an authoritarian system (Bodfis, 2018). Populist movements such as The Five Stars, which are considered to be the pioneers of digital democracy. They originated from a blog, but later developed a software platform called Rousseau, which enables active participation of members of the party when forming party policies. The software enables direct internal democracy with some limitations. Members of the movement can choose between approved candidates for local, regional, national and European elections, propose and discuss new laws and policies, and vote in consultations. However, the system is getting more and more critics due to its lack of transparency and strict supervision of the management of the parties over how it works. The system is subject to both technological (e.g., failure of the system at a time of significant voter support in the Senate) as ideological manipulations. An example of ideological manipulation is evident based on the candidate's nomination for the mayor of Rome. In the system, the candidates presented themselves through the video, and with 200 candidates for the mayor of Rome, the party's members dominated, voting for the outer 
appearance of the person, and not her real managerial ability and knowledge. Rome, in its mandate, is falling from crisis to crisis. The system's democratization is also questionable due to the relatively low number of registered users. The client has several million supporters in Italy, and the number of registered parties in the system is only 140,000 (Roberts, 2019).

The next chapter is intended to explain the influence of social innovative technological challenges on public value theory.

\subsection{Technological challenges and public value theory}

Public value theory is based on the coexistence of the values of three social elements: politicians, public managers (bureaucrats) and citizens (Moore, 1995; Moore and Khagram, 2004). The theory is based on a normative approach that enforces: (i) a process that creates value and a society that is dependent on the interplay between these three social elements, (ii) there are synergies with by which such interaction can be realized.

The original view of public benefit theory was that public officials are subordinate to politicians. Thus, the father of this theory, Mark Moore (1995, p. 38), described policies as the "ultimate arbiter" of public value, which gives them primacy in the context of public value formation. Moore (1995, pp. 54-55) was aware that political decision-making is not immune against various types of corruption and that these problems could affect how citizens and managers understand whether political decision-making was a moral act. During the first phase of development, which occurred in the first decade of the $21 \mathrm{st}$ century, various views emerged on the importance and integrity of public benefits. This involved the delegation of powers and thus the empowerment of public managers, which in theory is described as a fundamental compromise between "efficiency" and "democracy" (Stoker, 2006, p. 43). This led researchers such as Rhodes and Wanna (2007), among others, to criticize public value theory. The authors introduced public value as an inherently "undemocratic notion" (Rhodes and Wanna, 2007, p. 408), because increasing the power of public managers constitutes an open usurpation of power and thus suppresses democratic processes.

Public benefit theory has seen several claims saying it is well suited to integrating into neoliberal policies of rationalism (Jacobs, 2014). However, Moore (2014) rejected this with the thesis that the word "value" itself rejects the ideas of neoliberalism and limits government intervention in the market in order to remedy market failures, as presented in the previous subchapter. In Moore's view, his theory restores the government task of promoting equality and justice through the use of state powers.

Dunleavy and Margetts (2015) co-authored the theory of idealized digital governance as a hypothetically new form of state based on a small intelligent core. Its characteristics are that it retrieves data from the cloud, while its activities are limited primarily to policymaking, where citizens use different Internet platforms and become decision-makers through delegation by the government. This process leads to a genuinely post-bureaucratic and de-politicized "information state", in which the process of non-mediated governance will also play its role as a tool for citizen-led democratic control. The main objective of developing and implementing nonmediated governance in the future is to ensure complex governance, effectively without public administration (Paulin, 2019, p. 277). The system 
will also have to ensure that there are no administrative errors as a result of artificially intelligence systems. In fact, due to the non-interference of public and political administration, using it will be a significant step in taking advantage of abuse and corruption.

Big data, cyberspace, smart technologies, machine learning, algorithm development are all included in emerging technologies and have led to the formation of the second stage of the development of public value theory. The reason is that humanity has found itself in a period where technologies provide challenges to public leaders in an environment where technology corporations are increasingly influencing public discourse about public content. The public value theory has become an analytical tool for determining whether and how public leaders are aware of the importance of applying ethical rules and public benefits in conjunction with governance and regulation (e.g. European General Data Protection Regulation) (Andrews, 2019).

In order to understand the problem, it is necessary to first explain the importance and role of big data and algorithms in the public sector. Big data analysis is conducted, by storing and analysing both structured administrative data and those collected by public sector organization, as well as unstructured real-time data. Citizens generate this information and private entities through the use of interactive policy communications, enabling continuous interaction and exchange of information not only between humans (C2C), humans and machines interactions $(\mathrm{C} 2 \mathrm{M})$ but through machine-to-machine $(\mathrm{M} 2 \mathrm{M})$ interactions (Mergel et al., 2016). However, the result of such communication and the collection, analysis and storage of data in the cloud is not only an added value for the user or the public administration. For example, Turing (2017) points out that big data and machine learning work based on algorithms designed to enable self-learning and adaptation. The problem with these algorithms, however, is that they can be biased, as a result of human-generated data-based subjective judgment, as opposed to the objective mathematical equations that underly machine learning, however efforts are being made in this regard, particularly in creating algorithms that can report how they got to specific answers (Agrawal, Gans and Goldfarb, 2018; Rosenfeld and Kraus, 2018). Therefore, it is necessary for specific algorithms that are listed in the public domain of important algorithms and have the political valence to establish a system of governance and regulation, while being an upgrade from intuition-based decision making (Gillespie, 2017; Selbst and Barocas, 2018).

Public value theory is gaining a new role in addressing issues such as: (i) ethical dilemmas in determining whether big data contributes to public values (Boyd and Crawford, 2012); (ii) questions about who can collect, analyse and store public data, (iii) methods of collecting, processing and storing, (iv) ensuring data security in the context of data acquisition, processing and storage, (v) efficient use of data and in which cases can data be legitimately used for other public decision-making (Andrews, 2019)?

All of these issues are linked to social pluralism (e.g. different stakeholder interests), institutional complexity (multi-level leadership) and scientific uncertainty (Head and Alford, 2015). Indeed, in the context of the introduction of new technologies and the implications thereof, we cannot only talk about solving technical problems and finding answers to the challenges of artificial intelligence. The challenges facing public administration are not only cognitive-analytical but also include communication, political and institutional challenges (Andrews, 2019). Incremental approaches are retreating to transformative intervention. 
In practice, the informatization of processes in the public sector has had both good and bad applications. For example, the openness of public data enables public managers to increase efficiency, transparency and credibility by publishing accurate analyses of the use of public spending. Funding platforms, through participatory budget programs, increase public value and facilitate the development of direct democracy. However, at the same time, more and more structurally complex technological problems are emerging that are often unknown and whose knowledge is fragmented or less visible due to its concealment. In addition to these problems, conflicts arise due to different interests or uneven distribution of stakeholder power. Therefore, addressing this issue requires in-depth analysis, dialogue and resolution by affected stakeholders (Andrews, 2019). The society must also be aware of the negative consequences of technology. Thus, information technology has led to the unnecessary deaths of women with breast cancer in the UK. In the English public health information system, the algorithm released a certain number of women between the ages of 68 and 71 who were never invited to the examination (Barnett, 2018).

\section{Conclusions}

This paper provides a source that can be useful for academics, members of the political administration and public administration and urban centre stakeholders, as it delves into a topic that could potentially drastically increase the actualization of needs and wishes of all stakeholders, particularly those of citizens that previously could not easily participate in democratic processes. We would like to particularly emphasize that the content of the paper is also of interest to policy makers and members of civil society in developing countries, where the drivers of e-government evolution can also be seen, such as the interactions between ICT and socially innovative approaches in informatization. In these countries' models of e-democracy and the emergence of new civic technologies can help increase the role of citizens and other important stakeholders with improving democratic governance. Our opinion is that that this would increase focus on the needs and wishes of stakeholders, while creating better communication channels between the government (from local to state level) and stakeholders. Goal-oriented introduction of civil technologies, along with the implementation of the political strategies, enables a citizen oriented participative and decision-making approach. This would be especially important in local communities, where it would give more efficient results with de-bureaucratized and de-politicized processes that create a citizen that is democratic public policy decision - maker.

The particular research limitation of the paper is that no survey or experiment was conducted. The intention was to review existing literature and practical cases, in order to assess research on e-democracy. Further studies should be focused on the effect of advanced urban technologies on approaches to social innovations in e-government, particularly their importance for the evolution of e-democracy, its adoption approaches and difficulties of implementation in different countries (regions, towns and villages) and geopolitical regions.

\section{References}

Agrawal, A., Gans, J. and Goldfarb, A., 2018. Prediction machines: the simple economics of artificial intelligence. Cambridge: Harvard Business Press. 
Ahn, M. J. and Bretschneider, S., 2011. Politics of E-Government: E-Government and the political control of bureaucracy. Public Administration Review, 71(3), pp. 414-424.

Andrews, L., 2019. Public administration, public leadership and the construction of public value in the age of the algorithm and 'big data'. Public Administration, 97(2), pp. 296-310.

Anthopoulos, L. G., 2017. Smart utopia VS smart reality: Learning by experience from 10 smart city cases. Cities, 63, pp. 128-148.

Asatryan, Z., Baskaran, T., Grigoriadis, T. and Heinemann, F., 2017. Direct democracy and local public finances under cooperative federalism. The Scandinavian Journal of Economics, 119(3), pp. 801-820.

Barnett, H., 2018. Breast cancer scandal: Hundreds of women given cancer death sentence after computer error. Express. [online] Available at: <http://www.express.co.uk/ news/uk/954156/breast-cancer-news-jeremy-hunt-cancer-scandal-screening-lateststatement/> [Accessed 20 August 2019].

Bertoncel, T., Erenda, I. and Meško, M., 2018. Managerial Early Warning System as Best Practice for Project Selection at a Smart Factory. Amfiteatru Economic, 20(49), pp. 805-819.

Barzelay, M., 2001. The new public management: Improving research and policy dialogue. Berkley: University of California Press.

Berner, M., 2004. Current practices for involving citizens in local government budgeting: Moving beyond method. Public Administration Quarterly, 27(4), pp. 410-432.

Bertot, J. C., Jaeger, P. T. and Hansen, D., 2012. The impact of polices on government social media usage: Issues, challenges, and recommendations. Government Information Quarterly, 29(1), pp. 30-40.

Bevir, M., 2011. Governance and governmentality after neoliberalism. Policy \& Politics, 39(4), pp. 457-471.

Bickerton, C. and Accetti, C.I., 2015. Populism and technocracy: opposites or complements? Critical Review of International Social and Political Philosophy, 20(2), pp. 186-206.

Bingham, L., 2006. The new urban governance: Processes for engaging citizens and stakeholders. Review of Policy Research, 23(4), pp. 815-826.

Bindu, N., Sankar, C.P. and Kumar, K.S., (in press). Research collaboration and knowledge sharing in e-governance. Transforming Government: People, Process and Policy.

Bodfish, C., 2018. M5S would 'replace parliament with direct democracy'. Italian insider. [online] Available at: <http://www.italianinsider.it/?q=node/7025/> [Accessed 9 October 2019].

Bolívar, M.P.R. and Meijer, A.J., 2016. Smart governance: Using a literature review and empirical analysis to build a research model. Social Science Computer Review, 34(6), pp. 673-692.

Bourgon, J., 2007. Responsive, responsible and respected government: Towards a new public administration theory. International Review of Administrative Sciences, 73, pp. 7-26. 
Boyd, D. and Crawford, K., 2012. Critical questions for big data: Provocations for a cultural, technological, and scholarly phenomenon. Information, communication \& society, 15(5), pp. 662-679.

Brewer, G.A., Neubauer, B.J. and Geiselhart, K., 2006. Designing and implementing egovernment systems: Critical implications for public administration and democracy. Administration \& Society, 38(4), pp. 472-499.

Budd, L., 2007. Post-bureaucracy and reanimating public governance: A discourse and practice of continuity?. International Journal of Public Sector Management, 20(6), pp. 531-547.

Carlson, E., 2016. Finding partisanship where we least expect it: Evidence of partisan bias in a new African democracy. Political Behavior, 38(1), pp. 129-154.

Carter, L., Weerakkody, V., Phillips, B. and Dwivedi, Y.K., 2016. Citizen adoption of egovernment services: Exploring citizen perceptions of online services in the United States and United Kingdom. Information Systems Management, 33(2), pp. 124-140.

Ceruzzi, P. E. and Paul, E., 2003. A history of modern computing. Cambridge: MIT press.

Choudrie, J., Zamani, E.D., Umeoji, E. and Emmanuel, A., 2017. Implementing E-government in Lagos State: Understanding the impact of cultural perceptions and working practices. Government Information Quarterly, 34(4), pp. 646-657.

Citrin, J., 1974. Comment: The political relevance of trust in government. American Political Science Review, 68(3), pp. 973-988.

Cordelia, A., 2007. E-government: towards the e-bureaucratic form?. Journal of information technology, 22(3), pp. 265-274.

Coursey, D. and Norris, D. F., 2008. Models of e- government: Are they correct? An empirical assessment. Public administration review, 68(3), pp. 523-536.

Cummings, T.G. and Worley, C.G., 2014. Organization development and change. 10th ed. Stamford: Cengage learning.

De Blasio, E. and Sorice, M., 2018. Populism between direct democracy and the technological myth. Palgrave Communications, 4(1), p. 15.

Denhardt, R.B. and Denhardt, J.V., 2000. The new public service: Serving rather than steering. Public administration review, 60(6), pp. 549-559.

Denhardt, J.V. and Denhardt, R.B., 2015a. The new public service revisited. Public Administration Review, 75(5), pp. 664-672.

Denhardt, J.V. and Denhardt, R.B., 2015b. The new public service: Serving, not steering. New York: Routledge.

Drechsler, W., 2005. The rise and demise of the new public management. Post-autistic economics review, 33(14), pp. 17-28.

Dunn, W.N. and Miller, D.Y., 2007. A critique of the new public management and the neoWeberian state: advancing a critical theory of administrative reform. Public Organization Review, 7(4), pp. 345-358.

Dunleavy, P. and Margetts, H., 2015. Design principles for essentially digital governance. In: s.n., 111th Annual Meeting of the American Political Science Association. San Francisco, USA, 3-6 September 2015. S.1:s.n. 
Dutton, W.H. and Kraemer, K.L., 1979. The automation of bias: Computers and local government budgeting. Information Privacy, 1(7), pp. 303-311.

EESC, European Economic and Social Committee, 2016. Opinion of the European Economic and Social Committee on 'Social innovation, networking and digital communication' (own initiative opinion)'. Official Journal of the European Union, 2016/C 013/16. [online] Available at: <http://eur-lex.europa.eu/legal-content/ EN/TXT/PDF/?uri=CELEX:52014IE4902\&from=EN> [Accessed 20 September 2019].

Evans-Cowley, J. and Hollander, J. 2010. The new generation of public participation: Internet-based participation tools. Planning Practice \& Research, 25(3), pp. 397-408.

Florida, R., 2010. Who's your city?: How the creative economy is making where to live the most important decision of your life. Toronto: Vintage.

Fountain, J.E., 2001. Building the virtual state: Information technology and institutional change. Washington, DC: Brookings Institution.

Frederickson, H.G., Smith, K.B., Larimer, C.W. and Licari, M., 2012. The public administration theory primer. 2nd ed. Boulder: Westview Press.

Fuchs, D., 2006. Participatory, liberal and electronic democracy. In: T. Zittel and D. Fuchs eds., 2006. Participatory democracy and political participation. Oxon: Routledge, pp. $45-70$.

Giddens, A., 2009. The consequences of modernity. Cambridge: Polity Press.

Gillespie, T., 2014. The relevance of algorithms. In: T. Gillespie, P.J. Boczkowski and K-A. Foot eds., 2014. Media technologies: Essays on communication, materiality, and society. Cambridge: MIT Press, pp. 167-193.

Greiman, V., 2018. Reflecting on cyber governance for a new world order: An ontological approach. In: P. Demartini and M. Marchiori, ECRM 2018 17th European Conference on Research Methods in Business and Management. Rome, Italy, 12-13 July 2018. Rome: Academic Conferences and publishing limited.

Greve, C., 2010. Whatever happened to New public management?. In: s.n. Danish Political Science Association meeting. Copenhagen, Denmark, 4-5 November 2010. Copenhagen: Copenhagen Business School, International Center for Business and Politics.

Gruening, G., 2001. Origin and theoretical basis of New Public Management. International public management journal, 4(1), pp. 1-25.

Heeks, R.B., 2008. E-government for development. Manchester: Institute for Development Policy and Management, University of Manchester.

Henry, N., 2010. Public administration and public affairs. New Jersey: Prentice Hall.

Heeks, R., 2002. e-Government in Africa: Promise and practice. Information Polity, 7(2/3), pp. 97-114.

Hitpass, B. and Astudillo, H., 2019. Industry 4.0 challenges for business process management and electronic-commerce. Journal of theoretical and applied electronic commerce research, 14(1), pp. I-III.

Hoffman, S., 2017. Programming China: The Communist Party's autonomic approach to managing state security. Merics China Monitor, 44, pp. 1-12.

Holzer, M. and Charbonneau, E., 2008. Public management \& administration illustrated. Vol. I. Newark: National Center for Public Perfomance Rutgers Universty. 
Höpfl, H.M., 2006. Post-bureaucracy and Weber's "modern" bureaucrat. Journal of Organizational Change Management, 19(1), pp. 8-21.

Jackson, L., 2018. 'The Best Education Ever': Trumpism, Brexit, and new social learning. Educational Philosophy and Theory, 50(5), pp. 441-443.

Jacobs, L.R., 2014. The contested politics of public value. Public Administration Review, 74(4), pp. 480-494.

Josserand, E., Teo, S. and Clegg, S., 2006. From bureaucratic to post-bureaucratic: the difficulties of transition. Journal of Organizational Change Management, 19(1), pp. 54-64.

Jørgensent, B.T., 2012. Weber and Kafka: The rational and the enigmatic bureaucracy. Public Administration, 90(1), pp. 194-210

Kaufmann, D., Kraay, A. and Mastruzzi, M., 2011. The worldwide governance indicators: methodology and analytical issues. Hague Journal on the Rule of Law, 3(2), pp. 220-246.

Kaufmann, D., Kraay, A. and Mastruzzi, M., 2010. Response to 'What do the worldwide governance indicators measure?'. The European Journal of Development Research, 22(1), pp. 55-58.

Kim, C. K., 2007. A Cross-national Analysis of Global E-government. Public Organization Review, 7(4), pp. 317-329.

Kira, M. and Forslin, J., 2008. Seeking regenerative work in the post-bureaucratic transition. Journal of organizational change management, 21(1), pp. 76-91.

Kneuer, M., 2016. E-democracy: A new challenge for measuring democracy. International Political Science Review, 37(5), pp. 666-678.

Kooiman, J., 1993. Modern governance. New government - society interactions. London: SAGE Publications.

Laffin, M., 2018. Beyond bureaucracy?: The professions in the contemporary public sector. London: Routledge.

Layne, K. and Lee, J., 2001. Developing fully functional E-government: A four stage model. Government information quarterly, 18(2), pp. 122-136.

Lee, S. M., Tan, X. and Trimi, S., 2005. Current practices of leading e-government countries. Communications of the ACM, 48(10), pp. 99-104.

Lindner, R., Hennen, L. and Aichholzer, G., 2016. Electronic democracy in Europe. Berlin, Heidelberg, New York: Springer.

Lindquist, E., 2006. Organizing for policy implementation: The emergence and role of implementation units in policy design and oversight. Journal of Comparative Policy Analysis, 8(4), pp. 311-324.

Lu, N.L. and Nguyen, T.V., 2016. Online tax filing-e-government service adoption case of Vietnam. Modern Economy [e-journal] 7(12). https://doi.org/1498. 10.4236/ me.2016.712135

Marche, S. and McNiven, J.D., 2003. E- government and e- governance: the future isn't what it used to be. Canadian Journal of Administrative Sciences/Revue Canadienne des Sciences de l'Administration, 20(1), pp. 74-86.

Meijer, A.J., 2011. Networked coproduction of public services in virtual communities: From a government- centric to a community approach to public service support. Public Administration Review, 71(4), pp. 598-607. 
Meijer, A. and Bolívar, M.P.R., 2016. Governing the smart city: a review of the literature on smart urban governance. International Review of Administrative Sciences, 82(2), pp. 392-408.

Mergel, I., Rethemeyer, R.K. and Isett, K., 2016. Big data in public affairs. Public Administration Review, 76, pp. 928-937.

Merhi, M.I., 2018. Does National Culture Have Any Impact on E-Government Usage?. International Journal of Technology Diffusion, 9(3), pp. 29-45.

Miles, R.E., Snow, C.S., Mathews, J.A., Miles, G. and Coleman Jr.H.J., 1997. Organizing in the knowledge age: Anticipating the cellular form. Academy of Management Perspectives, 11(4), pp. 7-20.

Mistreanu, S., 2018. Life inside China's social credit laboratory. The party's massive experiment in ranking and monitoring Chinese citizens has already started. Foreign Policy. [online] Available at: <https://foreignpolicy.com/2018/04/03/life-inside-chinassocial-credit-laboratory/> [Accessed 9 September 2019].

Moore, M.H., 1995. Creating public value: Strategic management in government. Cambridge: Harvard University Press.

Moore, M. and Khagram, S., 2004. On creating public value: What business might learn from government about strategic management, Working paper of the corporate social responsibility initiative, Kennedy School of Government. Cambridge: Harvard University.

Moore, M., 2014. Public value accounting: Establishing the philosophical basis. Public Administration Review, 74, pp. 465-477.

Mosconi, F., 2015. The new European industrial policy: Global competitiveness and the manufacturing renaissance. London, England: Routledge.

Moulaert, F., Mehmood, A., MacCallum, D. and Leubolt, B. eds., 2017. Social innovation as a trigger for transformations: The role of research. Brussels: Directorate-Generale for Research and Innovation.

Moulder, E. and Carlee, R., 2010. Engaging citizens in the economic squeeze. Public Management, 92(5), pp. 14-17.

Müller, J.W., 2017. What is populism. London: Penguin Books

Nabatchi, T., 2012. Putting the "Public" back in public values research: Designing participation to identify and respond to values. Public Administration Review,72(5), pp. 699-708.

Nabatchi, T. and Mergel, I., 2010. Participation 2.0: Using internet and social media technologies to promote distributed democracy and create digital neighborhoods. [online] Available at: <http://kops.uni-konstanz.de/handle/123456789/38750> [Accessed 9 September 2019].

Nam, T., 2018. Examining the anti-corruption effect of e-government and the moderating effect of national culture: A cross-country study. Government Information Quarterly, 35(2), pp. 273-282.

Nam, T., 2019. Does e-Government raise effectiveness and efficiency?: Examining the cross-national effect. Journal of Global Information Management, 27(3), pp. 120-138.

Nguyen, N.A., 2016. A cross-cultural study on e-government services delivery. Electronic Journal Information Systems Evaluation Volume, 19(2), pp. 121-134. 
Open government initiative, 2000. About Open Government. [online] Available at: <https://obamawhitehouse.archives.gov/open/about> [Accessed 14 October 2019].

Paulin, A., 2019. Smart city governance. Amsterdam: Elsevier.

Paulin, A. and Welzer, T., 2013. A universal system for fair non-repudiable certified e-mail without a trusted third party. Computers \& Security, 32, pp. 207-218.

Peters, G.B., 2000. Governance and comparative politics. In: J. Pierre ed., 2000. Debating governance: Authority, steering and democracy. Oxford: Oxford University Press, pp. 36-53.

Pierre, J., 2000. Introduction: Understanding governance. In: J. Pierre ed., 2000. Debating governance: Authority, steering and democracy. Oxford: Oxford University Press, pp. 1-10.

Pitasi, A., Dib Brasil, N. and Portolese, G., 2018. Legislative innovation. Towards a global law. Making process: the case of global citizenship policy modelling. International Review of Sociology, 28(3), pp. 392-402.

Pollitt, C., 2009. Bureaucracies remember, post- bureaucratic organizations forget?. Public Administration, 87(2), pp. 198-218.

Pollitt, C. and Bouckaert, G., 2011. Public management reform. A comparative analysis: New public management, governance, and the Neo-Weberian state. 3rd ed. Oxford: Oxford University Press.

Raadschelders, J.C., 2010. Is American public administration detached from historical context? On the nature of time and the need to understand it in government and its study. The American Review of Public Administration, 40(3), pp.235-260.

Rehena, Z. and Jansen, M., 2019. Smart city of Pune. In: L. Anthopoulos ed., 2019. Smart city emergence: Cases from around the world. Amsterdam: Elsiever, pp. 261-282.

Reidolf, M. and Prause, T., 2012. EGOPRISE: Results and Outlooks. In: G. Prause, K. Hunke and F. Thessel eds., 2012. Transnational aspects of end-user-oriented e-services in the Baltic sea region: Final handbook of the EGOPRISE project. Berlin: Berliner Wissenschafts -Verlag, pp. 172-185.

Rhodes, R.A. and Wanna, J., 2007. The limits to public value, or rescuing responsible government from the platonic guardians. Australian Journal of Public Administration, 66(4), pp. 406-421.

Rhodes, R.A.W., 1996. The new governance: governing without government. Political studies, 44(4), pp. 652-667.

Roberts, H., 2019. 5Stars struggle to debug digital democracy. Politico. [online] Available at: <https://www.politico.eu/article/italy-5stars-digital-democracy-struggle/> [Accessed 12 July 2019].

Rosenfeld, A. and Kraus, S., 2018. Predicting human decision-making: From prediction to action. Synthesis Lectures on Artificial Intelligence and Machine Learning, 12(1), pp. 1-150.

Roth, S., 2018. Introduction: Contemporary Counter-Movements in the Age of Brexit and Trump. Sociological Research Online, 23(2), pp. 496-506.

Rowley, J., 2011. e-Government stakeholders-Who are they and what do they want? International journal of Information management, 31(1), pp. 53-62. 
Sá, F., Rocha, Á. and Cota, M.P., 2016. Potential dimensions for a local e-Government services quality model. Telematics and Informatics, 33(2), pp. 270-276.

Sanderson, I., 1998. Achieving best value through fundamental performance review. Working paper series number 6. Coventry: University of Warwick.

Sangki, J., 2018. Vision of future e-government via new e-government maturity model: Based on Korea's e-government practices. Telecommunications Policy, 42(10), pp. $860-871$.

Selbst, A.D. and Barocas, S., 2018. The intuitive appeal of explainable machines. Fordham Law Review, 87, pp. 1085-1112.

Seoul Metropolitan Government, 2019. Seoul e-Government. [online] Available at: <www.metropolis.org/sites/default/files/seoul_e-government_english.pdf/> [Accessed 17 September 2019].

Schedler, K. and Scharf, M.C., 2001. Exploring the interrelations between electronic government and the new public management. In: B. Schmid, K. Slabeva-Stanoevska and V. Tschammer eds., 2001. Towards the E-Society: E-Commerce, E-Business, and E-Government. Boston: Springer, pp. 775-788.

Scholl, H.J., 2003, January. E-government: a special case of ICT-enabled business process change. In: IEEE. 36th Annual Hawaii International Conference on System Sciences. S.l., n.d. s.l:s.n.

Shires, J. and Smeets, M., 2017. Contesting 'cyber'. New America Foundation. [online] Available at: <https://www.newamerica.org/cybersecurity-initiative/c2b/c2b$\log /$ contesting-cybe> [Accessed 5 September 2019].

Sivarajah, U., Irani, Z. and Weerakkody, V., 2015. Evaluating the use and impact of Web 2.0 technologies in local government. Government Information Quarterly, 32(4), pp. 473-487.

Stanley, J.W. and Weare, C., 2004. The effects of Internet use on political participation: Evidence from an agency online discussion forum. Administration \& Society, 36(5), pp. 503-527.

Stoker, G., 2006. Public value management: a new narrative for networked governance? The American review of public administration, 36(1), pp. 41-57.

Suri, P.K. ed., 2017. Strategic Planning and Implementation of E-Governance. Singapore: Springer.

Symon, G., 2000. Information and communication technologies and the network organization: A critical analysis. Journal of Occupational and Organizational Psychology, 73(4), pp. 389-414.

Thompson, P. and Alvesson, M., 2005. Bureaucracy at work: misunderstandings and mixed blessings. In: P. Gay du ed., 2005. The values of bureaucracy. New York: Oxford University Press, pp. 89-113.

Turing, A., 2017. How can we design fair, transparent, and accountable AI and robotics? Alan Turing Institute Blog. [blog] Available at: <https://www.turing.ac.uk/blog/candesign-fair-transparent-accountable-ai-robotics/> [Accessed 27 August 2019].

United Nations, 2018. United Nations E-government survey 2018. [pdf] New York: United Nations. Available at: <https://publicadministration.un.org/egovkb/Portals/egovkb/ 
Documents/un/2018-Survey/E-Government\%20Survey\%202018_FINAL\%20for\% 20web.pdf/> [Accessed 24 September 2019].

Verdegem, P. and Verleye, G., 2009. User-centered E-Government in practice: A comprehensive model for measuring user satisfaction. Government information quarterly, 26(3), pp. 487-497.

Vienna Declaration, 2011. The most relevant topics in social innovation research. [online] Available at: <http://www.socialinnovation2011.eu/wpcontent/uploads/2011/09/ ViennaDeclaration_final_10Nov2011.pdf/> [Accessed 3 November 2019].

Webster, C.W.R. and Leleux, C., 2018. Smart governance: Opportunities for technologically-mediated citizen co-production. Information Polity, 23(1), pp. 95-110.

Weerakkody, V., Janssen, M. and Dwivedi, Y.K., 2011. Transformational change and business process reengineering (BPR): Lessons from the British and Dutch public sector. Government Information Quarterly, 28(3), pp. 320-328.

WeGowNow, 2018. Towards We-Government: Collective and participative approaches for addressing local policy challenges. Consolidated conceptual \& methodological framework $v 1$. [online] Available at: <https://wegovnow.eu/fileadmin/wegovnow/ images/deliverables/d1.1_final.pdf/> [Accessed 24 September 2019].

Wilson, B. and Chakraborty, A., 2019. Planning Smart (er) Cities: The Promise of Civic Technology. Journal of Urban Technology, 26(4), pp. 1-23.

West, D.M., 2004. E- government and the transformation of service delivery and citizen attitudes. Public administration review, 64(1), pp. 15-27.

Zaidi, S.K.R., Henderson, D.C. and Gupta, G., 2017. The moderating effect of culture on e-filing taxes: evidence from India. Journal of Accounting in Emerging Economies, 7(1), pp. 134-152.

Zeemering, E.S., 2008. Governing interlocal cooperation: City council interests and the implications for public management. Public Administration Review, 68(4), pp. 731-741.

Zuboff, S., 2019. The age of surveillance capitalism: The fight for a human future at the new frontier of power. London: Profile Books Ltd. 